ARTICLE

\title{
The kaolinite shuttle links the Great Oxidation and Lomagundi events
}

Weiduo Hao (10 ${ }^{1 凶}$, Kaarel Mänd (1) 1,2, Yuhao Li ${ }^{1}$, Daniel S. Alessi [D ${ }^{1}$, Peeter Somelar ${ }^{2}$, Mathieu Moussavou ${ }^{3}$, Alexander E. Romashkin ${ }^{4}$, Aivo Lepland ${ }^{2,5,6}$, Kalle Kirsimäe ${ }^{2}$, Noah J. Planavsky (1) ${ }^{7}$ \& Kurt O. Konhauser ${ }^{1}$

The $2.22-2.06 \mathrm{Ga}$ Lomagundi Event was the longest positive carbon isotope excursion in Earth's history and is commonly interpreted to reflect perturbations in continental weathering and the phosphorous cycle. Previous models have focused on mechanisms of increasing phosphorous solubilization during weathering without focusing on transport to the oceans and its dispersion in seawater. Building from new experimental results, here we report kaolinite readily absorbs phosphorous under acidic freshwater conditions, but quantitatively releases phosphorous under seawater conditions where it becomes bioavailable to phytoplankton. The strong likelihood of high weathering intensities and associated high kaolinite content in post-Great-Oxidation-Event paleosols suggests there would have been enhanced phosphorus shuttling from the continents into marine environments. A kaolinite phosphorous shuttle introduces the potential for nonlinearity in the fluxes of phosphorous to the oceans with increases in chemical weathering intensity.

\footnotetext{
${ }^{1}$ Department of Earth and Atmospheric Sciences, University of Alberta, Edmonton, Canada. ${ }^{2}$ Department of Geology, University of Tartu, Tartu, Estonia.

${ }^{3}$ Department of Geology, University of Science and Technology of Masuku, Franceville, Gabon. ${ }^{4}$ Institute of Geology, Karelian Science Centre, Petrozavodsk, Russia.

${ }^{5}$ CAGE-Centre for Arctic Gas Hydrate, Environment and Climate, Department of Geosciences, UiT The Arctic University of Norway, Tromsø, Norway. ${ }^{6}$ Geological

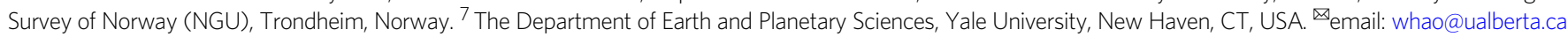


T he LE is the most pronounced and long-lived positive carbon isotope excursion in Earth history. Marine carbonate rocks deposited during the LE, which lasted at least 160 million years, are characterized by $\delta^{13} \mathrm{C}_{\text {carb }}$ values $>10$ (refs. ${ }^{1-4}$ ). The most widely accepted explanation for the LE relies on significant perturbation in the balance of different $\mathrm{C}$ burial fluxes-since organic carbon $\left(\mathrm{C}_{\text {org }}\right)$ is depleted in ${ }^{13} \mathrm{C}$, an increase in $\mathrm{C}_{\text {org }}$ burial compared to carbonate burial will result in ${ }^{13} \mathrm{C}$ enrichment of the dissolved marine carbonate pool ${ }^{2}$. Although it is likely that at least some of the carbonate $\delta^{13} \mathrm{C}$ values reflect local, instead of global, processes (e.g., ref. ${ }^{5}$ ), current explanations for the anomalously positive values require high rates of marine primary productivity. There is increasing consensus that $\mathrm{P}$ is likely to have been the ultimate limiting nutrient through Earth's history ${ }^{6,7}$. Accordingly, explanations for the LE must center around the factors which can induce $>100$ myr perturbations to the global P cycle.

Oxidation of a reduced mineral enriched upper continental crust during the LE provides one possible mechanism to drive extended changes in the phosphorous cycle ${ }^{8,9}$. The proliferation of aerobic chemolithoautotrophy would have facilitated the rapid biological weathering of crustal sulfide minerals, leading to an extended episode of acid rock drainage, and solubilization of nutrient-bearing minerals ${ }^{10}$ (e.g., apatite in rocks and soils, the weathering of which is highly $\mathrm{pH}$-dependent ${ }^{11}$ ). Similarly, extensive oxidation of siderite in aerially exposed sediments (e.g., shales, marls) during the LE would have led to high acid fluxes into soils and potentially promoted high atmospheric $\mathrm{CO}_{2}$ levels, increasing weathering regimes more broadly ${ }^{9}$. Elevated siderite and pyrite contents in the weatherable shell during the LE were simply a consequence of higher fluxes of reduced $\mathrm{S}$ and Fe to marine sediments during the Archean (e.g., refs. ${ }^{12-14}$ ). Upon weathering, $\mathrm{P}$ appears to have been mostly leached away and carried into the oceans, instead of retained in the paleosol (for instance, Hao et al. ${ }^{15}$ report a peak in paleosol P loss at $\sim 2.3-2.4$ $\mathrm{Ga}$ ). Kinetic and thermodynamic models further indicate that the weathering flux of $\mathrm{P}$ increased through the Archean, possibly reaching modern levels by the end of the eon ${ }^{15}$.

This driver of the LE assumes that higher acid fluxes will lead to greater P fluxes to the biosphere ${ }^{8,10}$. However, in the modern, typically $<10 \%$ of total $\mathrm{P}$ is transported via rivers as dissolved anions (for detailed discussion see supplementary note 1 ). Most is transported in the particulate phase ${ }^{16}$, including $\mathrm{P}$ adsorbed onto $\mathrm{Fe}(\mathrm{III})$-Al(III)-oxyhydroxides or clay minerals, or organically complexed ${ }^{17}$ (see Table S1). A large portion of adsorbed P is then sedimented in estuaries and marginal marine environments with the flocculation of particulate phases where they remain inaccessible to plankton until remobilization within the sediment pile $^{18}$. In the absence of plants, the only organic compounds delivered to the oceans would have been from degraded continental microbial mats ${ }^{19}$, which are unlikely to have had as large of an effect on the P cycle. Further, during the LE, ferric oxyhydroxides may have been solubilized in the generally sulfide and siderite-rich Paleoproterozoic soils, in a process similar to what is observed in some pyrite-rich black shale weathering environments today ${ }^{20}$. Building from this framework, it seems reasonable that clay minerals were an important vector by which $\mathrm{P}$ was delivered to the oceans at that time.

Different terrestrial weathering regimes will lead to the formation of widely varying secondary mineral assemblages-potentially leading to major changes in $\mathrm{P}$ sorption and transport to the oceans. In highly weathered soils today, kaolinite $\left.\left[\mathrm{Al}_{2} \mathrm{Si}_{2} \mathrm{O}_{5}(\mathrm{OH})_{4}\right)\right]$, and its hydrated form halloysite $\left[\mathrm{Al}_{2} \mathrm{Si}_{2} \mathrm{O}_{5}(\mathrm{OH})_{4} \cdot 2 \mathrm{H}_{2} \mathrm{O}\right]$, are often the only remaining clay mineral phases aside from $\mathrm{Fe}(\mathrm{III})$ - and $\mathrm{Al}(\mathrm{III})$-oxyhydroxides and quart $\mathrm{z}^{21}$. With higher weathering intensities due to a stronger acid flux from pyrite and siderite oxidation, as well as higher $\mathrm{CO}_{2}$ levels, kaolinite formation would have been widespread. This link is well developed in modern settings, with extensive kaolinite formation in soils developed on organic and pyrite-rich lithologies such as black shales 22,23 . Despite still constituting an important part of the clay fraction, clay minerals more characteristic of moderate terrestrial weathering conditions (e.g., smectites) are more rapidly dissolved in acidic environments ${ }^{21,24-26}$

Conceptually, increased fluxes of kaolinite generation postGOE are also expected due to an increase in continental area at $2.4 \mathrm{Ga}^{27-29}$, and intensified continental weathering in the warm climate aftermath of Huronian global glaciation ${ }^{30-32}$. While goethite and hematite formation under an oxygenated atmosphere may have driven increased $\mathrm{Al}$ substitution into these phases at the expense of kaolinite formation ${ }^{33,34}$, we consider it unlikely to have substantially decreased kaolinite fluxes, as ferric hydroxide solubility increases dramatically with lower $\mathrm{pH}$ and $\mathrm{Fe}^{3+}$ becomes the dominant pyrite oxidant in high acid production drainage environments ${ }^{9}$. Thus, in this work, we show the evidence of kaolinite generation in shales and paleosols postGOE, and the capacity of kaolinite shuttling P from land to the oceans. The subsequent bacteria growth experiments demonstrate that the delivery of $\mathrm{P}$ by kaolinite leads to the augmentation of coastal primary productivity.

\section{Results}

Kaolinite in post-GOE shales and paleosols. Consistent with the above view that an increase in kaolinite formation in the aftermath of the GOE, kaolinite is found in several LE successions. For example, the LST-12 drill core exposing the upper strata of the Francevillian Group in Gabon hosts organic-rich shales with sedimentary kaolinite alongside mixed-layer illite-smectite ${ }^{35}$ (supplementary note 2, and Figs. S1-S3). Despite the greenschist facies metamorphic overprint ${ }^{36}$, tentative traces of preserved kaolinite are also found in X-ray diffraction spectra in two shale intervals of drill core $\mathrm{OPH}$, which intersects the Zaonega Formation in Russia (supplementary note 2 and Fig. S1). There is also enhanced formation of kaolinite in paleosols formed around, and following, the GOE indicating intensive acidic continental weathering at that time ${ }^{37-46}$. However, it is important to note that it is not possible to estimate exactly how common kaolinite is from the rock record given that it is often transformed during burial metamorphism ${ }^{47}$. Nonetheless, clues about the extent of kaolinite formation and weathering intensity can be gleamed from the major elemental composition of paleosols. We examine Al-richness (compared to $\mathrm{Ca}, \mathrm{Na}, \mathrm{Mg}$, and $\mathrm{K}$ ) in a record of definitive, relatively well-preserved paleosols through the late Archean and early Proterozoic ( $n=10$; see supplementary note 3 and Supplementary Data 1), since kaolinite is the main Albearing phase in highly weathered soils. Some Archean paleosols, such as Mt. Roe ${ }^{45}$ (Fig. 1a), display strong Al enrichment, suggesting strong weathering and local kaolinite production either under a high- $\mathrm{CO}_{2}$ atmosphere during long period of weathering 39 , or in the presence of transient oxygenated conditions ${ }^{45}$. Notably, we observe that Al-richness peaks in soils formed between $2.4 \mathrm{Ga}$ and $2.0 \mathrm{Ga}$ (GOE and LE), compared to paleosols older or younger than this time bracket (Fig. 1a, b), suggesting that kaolinite was highly abundant in contemporary terrestrial weathering environments. This trend is not likely an artifact of the differing latitude at which these paleosols formed given that calculated paleolatitudes do not correspond to the above trend (Supplementary Data 2).

The shuttling of $\mathbf{P}$ by kaolinite from rivers to the oceans. We used static and dynamic adsorption experiments to demonstrate that kaolinite will more effectively shuttle $\mathrm{P}$ to the oceans than 

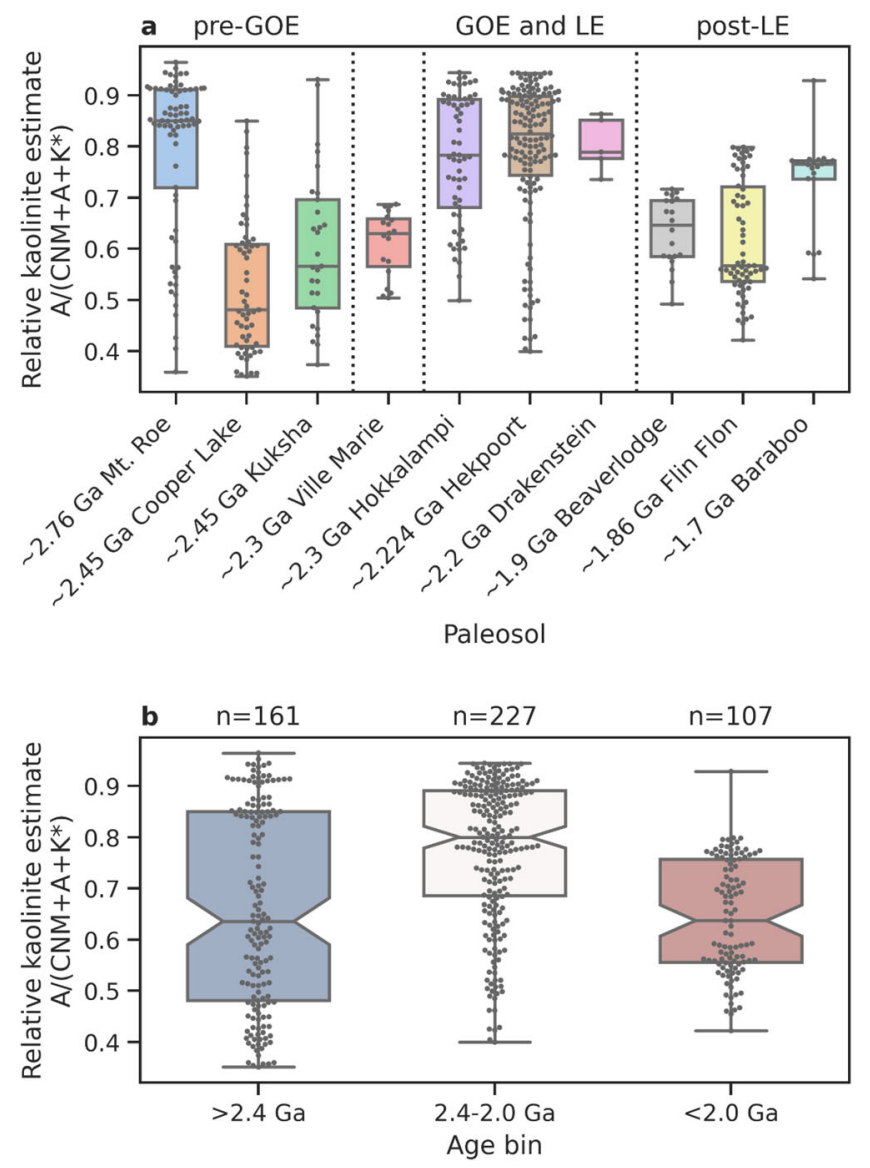

Fig. 1 Major element composition of Late Archean to Paleoproterozoic paleosols. Relative kaolinite contents are approximated by molar Alrichness, as compared to $\mathrm{Ca}, \mathrm{Na}, \mathrm{Mg}$, and $\mathrm{K}\left(\mathrm{CNM}=\mathrm{CaO}^{\star}+\mathrm{Na}_{2} \mathrm{O}+\right.$ $\mathrm{MgO}^{*} ; \mathrm{A}=\mathrm{Al}_{2} \mathrm{O}_{3} ; \mathrm{K}^{\star}=\mathrm{K}_{2} \mathrm{O}^{*}$; asterisks denote data corrected for nonsilicate contribution and K-metasomatism; Methods). a Al-richness in individual paleosols. The Ville Marie paleosol is poorly dated and may have formed either prior to or after the Great Oxidation Event (GOE), while its profile is possibly truncated with only the saprolite part preserved. Boxes show the mean value (horizontal line) and $25 \% / 75 \%$ quantiles (edges), whiskers show the full range. Superimposed dots denote individual samples. b Al-richness in paleosols within the pre-GOE (>2.4 Ga), GOE and LJE (2.4-2.0 Ga), and post-LJE (>2.4 Ga) age bins.

other typical clay minerals or oxides/hydroxides. In the static experiments we simulated freshwater $(\mathrm{pH} 4$ and ionic strength $0.01 \mathrm{M}$ ) to seawater-like ( $\mathrm{pH} 8$ and ionic strength $0.56 \mathrm{M}$ ) aqueous conditions, and also tested $\mathrm{P}$ adsorption to kaolinite at various initial phosphate concentrations to bracket modern riverine concentrations (Table S1). We stress that these conditions are meant to be representative of fresh and marine waters - they are not based on empirical- or model-based reconstruction of past $\mathrm{pH}$ values. For all initial $\mathrm{P}$ concentrations $<400 \mathrm{ppb}$ $(12.9 \mu \mathrm{M})$, the difference between the equilibrium adsorption experiments of simulated freshwater and seawater was negligible (Fig. 2). By contrast, at initial $\mathrm{P}$ concentrations $>400 \mathrm{ppb}$, there was $\sim 100-200 \mathrm{ppb}(3.2-6.4 \mu \mathrm{M})$ more $\mathrm{P}$ adsorbed in the freshwater environment than seawater. Surprisingly, ionic strength variations were found to be insignificant in modulating $\mathrm{P}$ adsorption compared to $\mathrm{pH}$ (similar trendlines for IS $=0.01 \mathrm{M}$ and $0.56 \mathrm{M}$ at the $\mathrm{pH} 8$ conditions; Fig. 2). However, the surface charge of kaolinite is $\mathrm{pH}$-dependent ${ }^{48,49}$. Surface complexation modeling based on acid-base titrations of kaolinite shows that kaolinite surface functional groups are highly protonated at $\mathrm{pH}<$

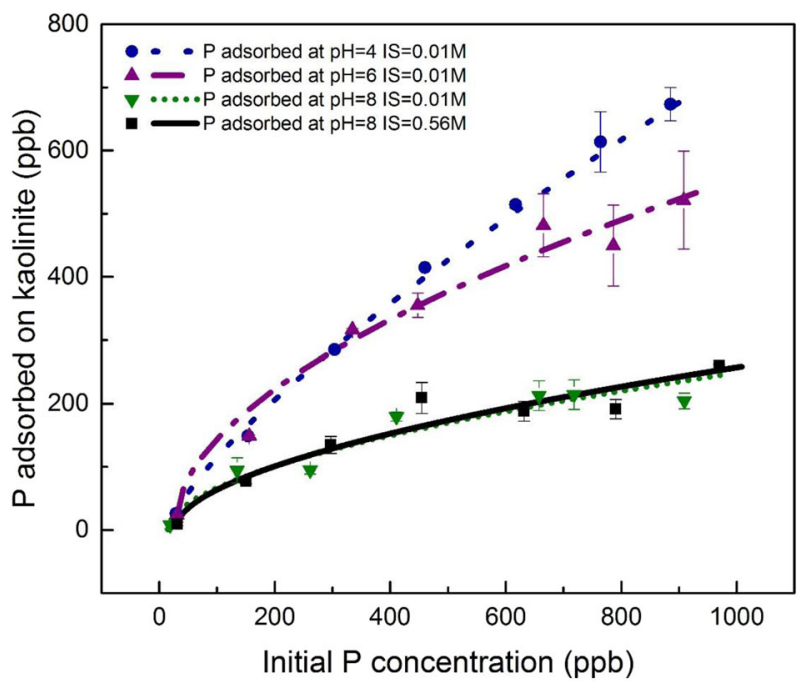

Fig. 2 The adsorption of $\mathbf{P}$ onto kaolinite at four different environmental conditions. Black squares and continuous line represent $\mathrm{P}$ adsorption at $\mathrm{pH} 8$, $\mathrm{IS}=0.56 \mathrm{M}$ conditions; green downward-facing triangles and dotted line represent $\mathrm{P}$ adsorption at $\mathrm{pH} 8, \mathrm{IS}=0.01 \mathrm{M}$ conditions; purple upward-facing triangles and dashed-dotted line show $\mathrm{P}$ adsorption at $\mathrm{pH} 6, \mathrm{IS}=0.01 \mathrm{M}$ conditions; blue circles and dashed line are $\mathrm{P}$ adsorption at $\mathrm{pH} 4, \mathrm{IS}=0.01 \mathrm{M}$ conditions. Error bars represent the \pm 1 standard deviation of replicates.

4.7, lending the clay a net positive charge (supplementary note 4), which can electrostatically attract negatively charged $\mathrm{P}$ species (dominantly $\mathrm{H}_{2} \mathrm{PO}_{4}^{-}$at $\mathrm{pH}$ 2-7). A bidentate mononuclear surface complex of $\mathrm{P}$ onto positively charged sites is the dominant adsorption mechanism on kaolinite, explaining the $\mathrm{pH}$ dependence of $\mathrm{P}$ adsorption (supplementary note 4 ).

To compare the results to clays more typical of moderate weathering regimes, we also examined the $\mathrm{P}$ adsorption capacities of illite and montmorillonite in both freshwater and marine conditions (data shown in supplementary note 5). We show that even under lower degrees of weathering characterized by montmorillonite and illite production, the transport of clays from rivers to the oceans can act as a P source simply due to variations in aqueous conditions. Importantly, however, the magnitude of $\mathrm{P}$ release is depressed when compared to kaolinite, suggesting that the kaolinite shuttle is more conducive to transporting $\mathrm{P}$ from land to the sea.

Dynamic adsorption experiments were performed to directly observe $\mathrm{P}$ behavior on kaolinite surfaces under simultaneously changing $\mathrm{pH}$ and ionic strength conditions (Fig. 3). At a $\mathrm{P}$ concentration of $\sim 155 \mathrm{ppb}(5 \mu \mathrm{M}), 95 \%$ of the $\mathrm{P}$ was adsorbed onto kaolinite surfaces at shale weathering conditions $(\mathrm{pH} 4)$. After switching to marine conditions ( $\mathrm{pH}$ of 8 ), the proportion of adsorbed $\mathrm{P}$ steadily declined throughout our experimental period (3 days). In total, $20 \%$ of pre-adsorbed $\mathrm{P}$ was released into the aqueous environment. As a comparison, we also analyzed $\mathrm{P}$ sorption to $\mathrm{Fe}(\mathrm{III})$-oxides and $\mathrm{Al}(\mathrm{III})$-hydroxide, such as hematite $\left(\mathrm{Fe}_{2} \mathrm{O}_{3}\right)$ and gibbsite $\left(\mathrm{Al}[\mathrm{OH}]_{3}\right)$, respectively, as both minerals represent stable mineral oxide phases under extreme weathering environments (e.g., laterites ${ }^{23,50}$ ). For both hematite and gibbsite, we show $100 \%$ adsorption of $\mathrm{P}$ at freshwater conditions but negligible release at seawater $\mathrm{pH}$ and ionic strength (Fig. 3).

Augmentation of nearshore primary bioproductivity. To confirm that the desorbed $\mathrm{P}$ in our experiments will be truly bioavailable, we also explored the impact of $\mathrm{P}$ bearing kaolinite input to the growth of the marine cyanobacterium Synechococcus sp. 


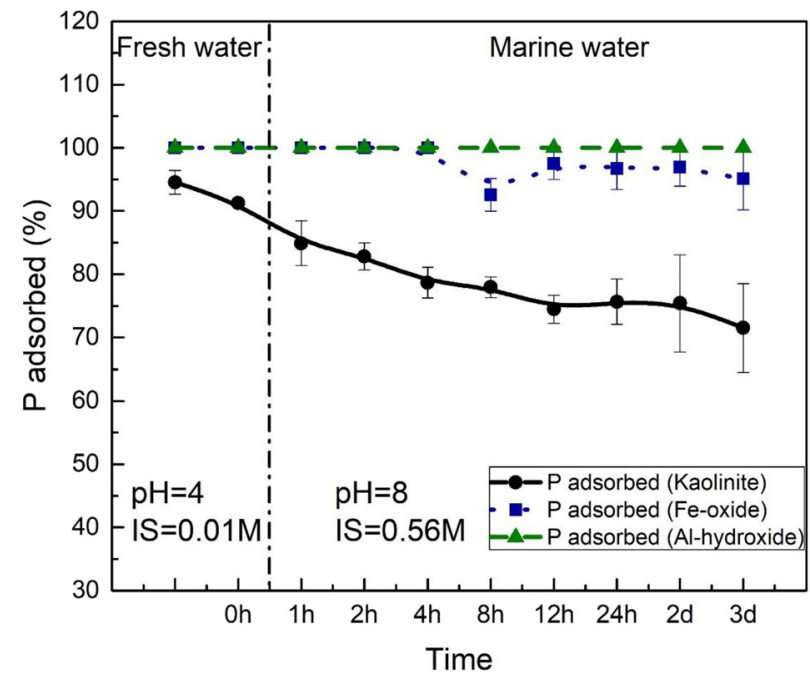

Fig. 3 Desorption of $\mathbf{P}$ from kaolinite, Fe-oxide and Al-hydroxide surfaces when transitioning from freshwater to marine conditions. Freshwater conditions were simulated at $\mathrm{pH} 4$ and ionic strength $=0.01 \mathrm{M}$, while marine conditions refer to $\mathrm{pH} 8$ and ionic strength $=0.56 \mathrm{M}$. The black circles and continuous line represent $P$ desorption from kaolinite surfaces; blue squares and dotted line show the $\mathrm{P}$ desorption from Fe-oxide; green triangles and dashed line show $\mathrm{P}$ desorption from Al-hydroxide. Error bars represent the \pm 1 standard deviation of replicates.

PCC 7002 in continuous culture; this species comprises a significant fraction of the modern marine phytoplankton ${ }^{51}$. Without clay input, cell density reached a plateau at the 2 nd day and then decreased to $5 \times 10^{6}$ cells $/ \mathrm{mL}$ ( $55 \%$ of initial density) at the 14 th day, while with $1 \mathrm{~g} / \mathrm{L}$ of P-bearing clay input, the cell number reached $8 \times 10^{6}$ cells $/ \mathrm{mL}$ ( $97 \%$ of initial density) at the end of the growth period. A $2 \mathrm{~g} / \mathrm{L}$ P-bearing kaolinite input led to a bacterial cell density of $1.2 \times 10^{7}$ (139\% of initial density), more than twice that of the blank (Fig. 4). In summary, the high adsorption capacity of kaolinite under freshwater conditions and its low capacity under marine conditions results in enhanced $\mathrm{P}$ bioavailability and cyanobacterial productivity in post-GOE nearshore environments.

\section{Discussion}

It should still be noted that kaolinite shuttling would not have been the sole process providing bioavailable $\mathrm{P}$ to marine primary producers after the GOE. For example, although $\mathrm{P}$ release from $\mathrm{Fe}$ (III)- and $\mathrm{Al}(\mathrm{III})$-hydroxides is not as efficient as from kaolinite, bound $\mathrm{P}$ can be released from sediments to the water column over longer periods during early diagenesis ${ }^{52}$. Additionally, since Paleoproterozoic oceans were likely redox-stratified, some ferric oxyhydroxides would have been reductively dissolved below the redoxcline, and the released $\mathrm{P}$ made bioavailable through upwelling ${ }^{53}$. Smectite (montmorillonite) and illite, though showing a relatively lower $\mathrm{P}$ shuttling capacity compared to kaolinite (supplementary note 5), may also have contributed to nutrient shuttling during the Lomagundi Event, as, again, suggested by the preservation of smectite-rich clay minerals in Francevillian black shales ${ }^{35,54}$ and major elemental compositions close to average smectite composition in contemporary paleosols (Fig. S3). It is also worth noting that any changes in terrestrial $\mathrm{P}$ inputs are going to be modulated by the marine $\mathrm{P}$ cycle. For instance, coupled $\mathrm{P}$ and Fe enrichment in the Francevillian basin, which was likely influenced by upwelling (e.g., refs. ${ }^{55,56}$ ), is likely a signal of $\mathrm{Fe}$ control on marine $\mathrm{P}$ cycling. Nonetheless, we highlight that the kaolinite shuttle added upon, and compounded,

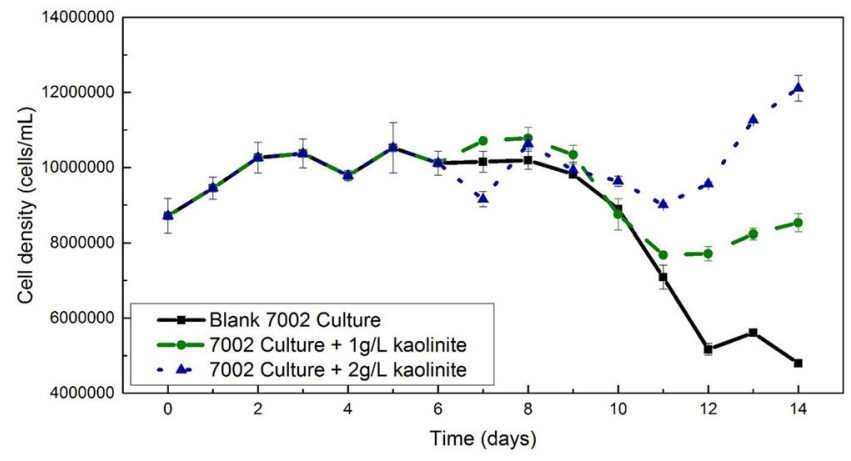

Fig. 4 Growth curves of Synechococcus sp. PCC7002 at different levels of added P-bearing kaolinite. The original culture was divided into three $150 \mathrm{~mL}$ sub-cultures after day 6 . Black squares and straight line represent the control culture incubated in modified $\mathrm{A}+$ growth media with only $5 \mu \mathrm{M}$ potassium phosphate. The green circles and dashed line show the growth of a culture with addition of $150 \mathrm{mg}$ of P-bearing kaolinite after day 6 . The blue triangles and dotted line represent the culture in which $300 \mathrm{mg}$ of P-bearing kaolinite was added after day 6 . Error bars represent the \pm 0.5 standard deviation of replicates.

these prior P-fertilization mechanisms to significantly increase the supply of bioavailable $\mathrm{P}$ to nearshore ecosystems.

It is also possible that the kaolinite shuttle was turned on during other extreme global carbon cycle and biogeochemical perturbations in Earth's past marked by anomalously high primary productivity (e.g., the Permian Triassic biotic crisis; Paleocene-Eocene Thermal Maximum (PETM)). For example, the PETM is characterized by a rise of surface temperature $\left(5-8{ }^{\circ} \mathrm{C}\right)$ and extensive continental weathering (e.g., ref. $\left.{ }^{57}\right)$. Consistent with our view, there are spikes in kaolinite formation during the PETM in several regions ${ }^{58,59}$. A compilation of marine sediments from the P-E boundary demonstrates a dramatic increase in kaolinite generation (approaching $80 \%$ of kaolinite in clay phases) during the PETM period (supplementary note 6, Supplementary Data 3, and Fig. S11). The shuttle of kaolinite from land to the oceans would have increased marine bio-productivity, induced the storage of $\mathrm{CO}_{2}$ into ${ }^{13} \mathrm{C}$-depleted organic carbon, and subsequently recover the post-PETM $\delta^{13} \mathrm{C}_{\text {carb }}$ to Paleocene values (see ref. ${ }^{57}$ ).

The kaolinite shuttle provides a novel mechanism to tie together known threads of Earth's biogeochemical environment following the initial rise of atmospheric oxygen - increased acid weathering and enhanced primary productivity. A critical aspect of the model is that the response of the $\mathrm{P}$ cycle to weathering intensity is non-linear. Phosphorous fluxes became greatly enhanced when intense terrestrial weathering conditions that produced abundant kaolinite became spatially widespread. Strong nonlinearity in the extent of $\mathrm{P}$ shuttling could help explain why the Lomagundi stands out as a unique event in Earth's history. Reconstructing mineralogical trends in deep time events and from Lomagundi-aged sediments is difficult given clay transformation with burial, but more recent "weathering events" (e.g., the PETM) bolster the case that there is a link between terrestrial weathering regimes, nutrient fluxes, intervals of anoxia, extinction, and ecosystem transitions.

\section{Methods}

The paleosol chemical database of eight relatively complete paleosols ranging in age from $2.76 \mathrm{Ga}$ to $1.70 \mathrm{Ga}$ was compiled from published paleosol studies and used to assess trends in weathering intensity through the time period. $\mathrm{Al}, \mathrm{Ca}, \mathrm{Na}, \mathrm{Mg}$, and $\mathrm{K}$ were plotted on a CNM-A-K ternary plot, modified from the $\mathrm{CN}-\mathrm{A}-\mathrm{K}$ plot of Nesbitt and Young ${ }^{30}$. The addition of $\mathrm{M}(\mathrm{Mg})$ was to separate Al-rich kaolinite/ gibbsite - proxies for acid weathering - from $\mathrm{Al}$ and $\mathrm{Mg}$-rich chlorite, which is a common diagenetic-metamorphic mineral. The paleosol database was scrubbed of samples representing cover rocks and soils developed on chemical sediments. $\mathrm{Ca}$ 
and $\mathrm{Mg}$ were corrected for carbonate and apatite content, and $\mathrm{K}$ for $\mathrm{K}$ metasomatism. For the detailed methodology, see supplementary note 3 . The mineral composition (Fig. S1) of mudstones in drill core LST-12 (Francevillian Group, Gabon) and OPH (Zaonega Formation, Russia) was determined by X-ray diffractometry using a Bruker D8 Advance diffractometer with $\mathrm{Cu} \mathrm{Ka}$ radiation and a LynxEye positive sensitive detector. The measured patterns were interpreted and modeled using the Rietveld algorithm-based program Topaz. The relative error of quantification is better than $10 \%$ for major phases $(>5 \mathrm{wt} \%)$ and better than $20 \%$ for minor phases $(<5 \mathrm{wt} \%)$. For the geological setting, location and description of the successions see ref. ${ }^{60}$ for core LST-12, and refs. ${ }^{61-63}$ for the OPH core.

Phosphate equilibrium adsorption experiments onto three clay minerals (kaolinite, illite, and montmorillonite) were performed at the following phosphate concentrations: $1,5,10,15,20,25$, and $30 \mu \mathrm{M}$. A 5-mM Na${ }_{2} \mathrm{HPO}_{4}$ stock solution was prepared by dissolving $\mathrm{Na}_{2} \mathrm{HPO}_{4}$ salt (ACS certified, Fisher Scientific) into MQ water. Solutions of different phosphate concentration were prepared by diluting the stock solution with a $0.01-\mathrm{M} \mathrm{NaCl}$ or $0.56-\mathrm{M} \mathrm{NaCl}$ solution to a total volume of 50 $\mathrm{ml}$. Then, $5 \mathrm{ml}$ of solution was pipetted to analyze the initial phosphate concentration. After that, $45 \mathrm{mg}$ of clay was added into solution to make a $1-\mathrm{g} / \mathrm{L}$ solid suspension. After agitation, the solution $\mathrm{pH}$ of each experiment was adjusted to 4, 6 , and 8 separately using $0.1 \mathrm{M} \mathrm{HCl}$ and $0.1 \mathrm{M} \mathrm{NaOH}$. The solution $\mathrm{pH}$ was consistently maintained during the adsorption period. Once equilibrium was reached, $5 \mathrm{ml}$ of clay suspension was pipetted and filtered through a $0.2-\mu \mathrm{m}$ filter. The filtrate and the initial $5 \mathrm{ml}$ solution were acidified for ICP-MS analysis. All experiments were performed in duplicate.

Phosphate dynamic adsorption experiments were performed in a 500-ml beaker. For simulation of freshwater conditions, $400 \mathrm{ml}$ of $0.01 \mathrm{M} \mathrm{NaCl}$ solution was added to a glass beaker. Then, $0.4 \mathrm{~mL}$ of $5 \mathrm{mM} \mathrm{Na}_{2} \mathrm{HPO}_{4}$ stock solution was added to make a 5- $\mu \mathrm{M}$ phosphate solution. A magnetic stir bar was added to keep the solution mixing during the whole experimental period. Once well mixed, a 5-ml aliquot was taken for initial phosphate concentration analysis. After, the solution $\mathrm{pH}$ was adjusted to 4 with small aliquots of $0.1 \mathrm{M} \mathrm{HCl}$ and $0.1 \mathrm{M} \mathrm{NaOH}$, mimicking freshwater conditions, and $0.395 \mathrm{~g}$ of kaolinite was added into the beaker to make a $1 \mathrm{~g} / \mathrm{L}$ clay suspension. The adsorption of phosphate onto clays under the freshwater condition lasted $24 \mathrm{~h}$ and during this process, the $\mathrm{pH}$ was maintained at 4 using $0.1 \mathrm{M} \mathrm{HCl}$ and $0.1 \mathrm{M} \mathrm{NaOH}$ solution. After $24 \mathrm{~h}$, a $5-\mathrm{ml}$ aliquot was syringed out and filtered through a $0.2 \mu \mathrm{m}$ filter for ICP-MS analysis. Then, the solution $\mathrm{pH}$ was adjusted to 8 by a $0.1-\mathrm{M} \mathrm{NaOH}$ solution and $12.87 \mathrm{~g}$ of $\mathrm{NaCl}$ was added into the beaker at the same time to adjust the ionic strength to $0.56 \mathrm{M}$, representing marine water conditions. Once the $\mathrm{pH}$ stabilized, a 5-ml aliquot was collected for phosphate concentration analysis at $t=0$. The whole marine condition adsorption process took 2 days and the time intervals of sample collection were $t=0, t=1 \mathrm{~h}, t=2 \mathrm{~h}, t=4 \mathrm{~h}, t=8 \mathrm{~h}, t=12 \mathrm{~h}, t=1 \mathrm{~d}$, and $t=2 \mathrm{~d}$. During the experiment, the reaction beaker was covered by parafilm to prevent possible solution evaporation. Same procedure was applied to Al-hydroxide and Fe-oxide. The phosphate concentration in these samples was analyzed by ICP-MS. Detailed experimental information could also be found in Hai et al. ${ }^{64}$.

The cyanobacterium Synechococcus sp. PCC7002 was used as an analog strain in the growth experiment to analyze its response to the addition of P-bearing kaolinite clay. This axenic strain was incubated in a modified A + growth media with a limited phosphate concentration of $5 \mu \mathrm{M}$. All cultures were grown on a shaker in a designated growth chamber that was set at $30^{\circ} \mathrm{C}$ with constant halogen lighting. A sterile 1-L Erlenmeyer flask with $550 \mathrm{~mL}$ of modified A+ growth media was initially inoculated from an axenic PCC 7002 culture growing on an agar plate. The growth of the microbial culture was monitored by optical density at $750 \mathrm{~nm}$ (OD $750 \mathrm{~nm}$ ) on a daily basis after inoculation. The growth curve started at day 0 when the OD $750 \mathrm{~nm}$ absorbance was above 0.15 . A triplicate of $1 \mathrm{~mL}$ cultures was extracted sterilely from the flask each day for Chlorophyll-a concentration analysis as an indicator of cell growth from day 0 . When it was certain that the culture reached the stationary phase, at which time the Chlorophyll-a concentration stopped increasing at $\sim 0.680 \mu \mathrm{g} / \mathrm{mL}$, the culture was further divided into three $150 \mathrm{~mL}$ sub-cultures in $500 \mathrm{~mL}$ Erlenmeyer flasks. Immediately after sub-culturing, $150 \mathrm{mg}$ and $300 \mathrm{mg}$ of P-bearing kaolinite were added into two of the three subcultures to make a $1 \mathrm{~g} / \mathrm{L}$ and $2 \mathrm{~g} / \mathrm{L}$ kaolinite suspension, respectively. The last subculture was the control where no clay was added. All three cultures were continuously examined for cell growth by Chlorophyll-a concentration until day 14 when there was a clear cell density difference among three sub-cultures (Fig. 4). Both optical density at $750 \mathrm{~nm}$ and chlorophyll-a concentration was measured on a Beckman Coulter DU ${ }^{\circledR 520}$ UV/VIS spectrophotometer. The chlorophyll-a concentration was lastly converted to cell density using a correlation that was established from a standard growth curve, which was systematically quantified by both chlorophyll-a concentration and cell density that was measured on an Attune NXT acoustic focusing flow cytometer (Fig. 4).

\section{Data availability}

The authors declare that the main data supporting the findings of this study are available in the following Data Repository link: https://doi.org/10.17632/dmhfrympsr.1.

\section{Code availability}

Code available at https://doi.org/10.5281/zenodo.4641971.
Received: 28 October 2020; Accepted: 19 April 2021; Published online: 19 May 2021

\section{References}

1. Bekker, A., Karhu, J. A., Eriksson, K. A. \& Kaufman, A. J. Chemostratigraphy of Paleoproterozoic carbonate successions of the Wyoming Craton: tectonic forcing of biogeochemical change? Precambrian Res. 120, 279-325 (2003).

2. Karhu, J. A. \& Holland, H. D. Carbon isotopes and the rise of atmospheric oxygen. Geology 24, 867-870 (1996).

3. Schidlowski, M., Eichmann, R. \& Junge, C. E. Carbon isotope geochemistry of Precambrian Lomagundi carbonate province, Rhodesia. Geochim. Cosmochim. Acta 40, 449-455 (1976).

4. Melezhik, V. A., Fallick, A. E., Medvedev, P. V. \& Makarikhin, V. V. Extreme C-13Ccarb enrichment in ca, 2.0 Ga magnesite-stromatolite-dolomite-'red beds' association in a global context: a case for the world-wide signal enhanced by a local environment. Earth Sci. Rev. 48, 71-120 (1999).

5. Geyman, E. C. \& Maloof, A. C. A diurnal carbon engine explains 13Cenriched carbonates without increasing the global production of oxygen. Proc Natl Acad. Sci. USA 116, 24433-24439 (2019).

6. Reinhard, C. T. et al. Evolution of the global phosphorus cycle. Nature 541, 386-389 (2017).

7. Laakso, T. A. \& Schrag, D. P. Limitations on limitation. Glob. Biogeochem. Cycles 32, 486-496 (2018).

8. Bekker, A. \& Holland, H. D. Oxygen overshoot and recovery during the early Paleoproterozoic. Earth Planet. Sci. Lett. 317, 295-304 (2012).

9. Bachan, A. \& Kump, L. R. The rise of oxygen and siderite oxidation during the Lomagundi Event. Proc. Natl Acad. Sci. USA 112, 6562-6567 (2015).

10. Konhauser, K. O. et al. Aerobic bacterial pyrite oxidation and acid rock drainage during the Great Oxidation Event. Nature 478, 369-373 (2011).

11. Smith, E. A., Mayfield, C. I. \& Wong, P. T. S. Physical and chemical characterization of selected natural apatites in synthetic and natural aqueous solutions. Water Air Soil Pollut. 8, 401-415 (1977).

12. Rosas, J. C. \& Korenaga, J. Rapid crustal growth and efficient crustal recycling in the early Earth: implications for Hadean and Archean geodynamics. Earth Planet. Sci. Lett. 494, 42-49 (2018).

13. Kump, L. R. \& Seyfried, W. E. Hydrothermal Fe fluxes during the Precambrian: effect of low oceanic sulfate concentrations and low hydrostatic pressure on the composition of black smokers. Earth Planet. Sci. Lett. 235, 654-662 (2005).

14. Kump, L. R. \& Barley, M. E. Increased subaerial volcanism and the rise of atmospheric oxygen 2.5 billion years ago. Nature 448, 1033-1036 (2007).

15. Hao, J., Knoll, A. H., Huang, F., Hazen, R. M. \& Daniel, I. Cycling phosphorus on the Archean Earth: Part I. Continental weathering and riverine transport of phosphorus. Geochim. Cosmochim. Acta 273, $70-84$ (2020).

16. Froelich, P. N. Kinetic control of dissolved phosphate in natural rivers and estuaries: a primer on the phosphate buffer mechanism 1. Limnol. Oceanogr. 33, 649-668 (1988).

17. Gérard, F. Clay minerals, iron/aluminum oxides, and their contribution to phosphate sorption in soils - A myth revisited. Geoderma 262, 213-226 (2016).

18. Conley, D. J., Smith, W. M., Cornwell, J. C. \& Fisher, T. R. Transformation of particle-bound phosphorus at the land-sea interface. Estuar. Coast. Shelf Sci. 40, 161-176 (1995)

19. Lalonde, S. V. \& Konhauser, K. O. Benthic perspective on Earth's oldest evidence for oxygenic photosynthesis. Proc. Natl Acad. Sci. USA 112, 995-1000 (2015).

20. Joeckel, R. M., Ang Clement, B. J. \& VanFleet Bates, L. R. Sulfate-mineral crusts from pyrite weathering and acid rock drainage in the Dakota Formation and Graneros Shale, Jefferson County, Nebraska. Chem. Geol. 215, 433-452 (2005).

21. Velde, B. B. \& Meunier, A. The Origin Of Clay Minerals In Soils And Weathered Rocks. p. 219-226 (Springer-Verlag, 2008)

22. Fischer, C., Schmidt, C., Bauer, A., Gaupp, R. \& Heide, K. Mineralogical and geochemical alteration of low-grade metamorphic black slates due to oxidative weathering. Geochemistry 69, 127-142 (2009).

23. Jin, L. et al. Evolution of porosity and geochemistry in Marcellus Formation black shale during weathering. Chem. Geol. 356, 50-63 (2013).

24. Bibi, I., Singh, B. \& Silvester, E. Dissolution of illite in saline-acidic solutions at $25^{\circ} \mathrm{C}$. Geochim. Cosmochim. Acta 75, 3237-3249 (2011).

25. Bibi, I., Singh, B. \& Silvester, E. Dissolution kinetics of soil clays in sulfuric acid solutions: Ionic strength and temperature effects. Appl. Geochem. 51, 170-183 (2014).

26. Hao, W. et al. Effect of acidic conditions on surface properties and metal binding capacity of clay minerals. ACS Earth Space Chem. 3, 2421-2429 (2019). 
27. Lee, C.-T. A. et al. Two-step rise of atmospheric oxygen linked to the growth of continents. Nat. Geosci. 9, 417-424 (2016).

28. Korenega, J., Planavsky, N. J. \& Evans, D. A. D. Global water cycle and the coevolution of the Earth's interior and surface environment. Philos. Trans. $R$. Soc. Ser. A 375, 20150393 (2017).

29. Guo, M. \& Korenaga, J. Argon constraints on the early growth of felsic continental crust. Sci. Adv. 6, eaaz6234 (2020).

30. Nesbitt, H. W. \& Young, G. Early Proterozoic climates and plate motion inferred from major element chemistry of lutites. Nature 299, 715 (1982).

31. Papineau, D., Mojzsis, S. J. \& Schmitt, A. K. Multiple sulfur isotopes from Paleoproterozoic Huronian interglacial sediments and the rise of atmospheric oxygen. Earth Planet. Sci. Lett. 255, 188-212 (2007).

32. Tang, H. \& Chen, Y. Global glaciations and atmospheric change at ca. $2.3 \mathrm{Ga}$. Geosci. Front. 4, 583-596 (2013).

33. Trolard, F. \& Tardy, Y. The stabilities of gibbsite, boehmite, aluminous goethites and aluminous hematites in bauxites, ferricretes and laterites as a function of water activity, temperature and particle size. Geochim. Cosmochim. Acta 51, 945-957 (1987).

34. Trolard, F. \& Tardy, Y. A model of $\mathrm{Fe}^{3+}$-kaolinite, $\mathrm{Al}^{3+}$-goethite, $\mathrm{Al}^{3}$ +-hematite equilibria in laterites. Clay Miner. 24, 1-21 (1989).

35. Ossa, F. O. et al. Exceptional preservation of expandable clay minerals in the ca. 2.1 Ga black shales of the Francevillian basin, Gabon and its implication for atmospheric oxygen accumulation. Chem. Geol. 362, 181-192 (2013).

36. Melezhik, V. A., Fallick, A. E., Filippov, M. M. \& Larsen, O. Karelian shungite an indication of 2.0-Ga-old metamorphosed oil-shale and generation of petroleum: geology, lithology and geochemistry. Earth Sci. Rev. 47, 1-40 (1999).

37. Bandopadhyay, P., Eriksson, P. \& Roberts, R. A vertic paleosol at the ArcheanProterozoic contact from the Singhbhum-Orissa craton, eastern India. Precambrian Res. 177, 277-290 (2010).

38. de Wall, H., Pandit, M. K. \& Chauhan, N. K. Paleosol occurrences along the Archean-Proterozoic contact in the Aravalli craton, NW India. Precambrian Res. 216, 120-131 (2012).

39. Soomer, S. et al. High- $\mathrm{CO}_{2}$, acidic and oxygen-starved weathering at the Fennoscandian Shield at the Archean-Proterozoic transition. Precambrian Res. 327, 68-80 (2019).

40. Retallack, G. J. \& Krinsley, D. H. Metamorphic alteration of a Precambrian $(2.2 \mathrm{Ga})$ paleosol from South Africa revealed by backscattered electron imaging. Precambrian Res. 63, 27-41 (1993).

41. Gutzmer, J. \& Beukes, N. J. Earliest laterites and possible evidence for terrestrial vegetation in the Early Proterozoic. Geology 26, 263-266 (1998).

42. Gall, Q. The Proterozoic Thelon paleosol, Northwest Territories, Canada. Precambrian Res. 68, 115-137 (1994).

43. Rye, R. \& Holland, H. D. Paleosols and the evolution of atmospheric oxygen: a critical review. Am. J. Sci. 298, 621-672 (1998).

44. Nedachi, Y., Nedachi, M., Bennett, G. \& Ohmoto, H. Geochemistry and mineralogy of the 2.45 Ga Pronto paleosols, Ontario, Canada. Chem. Geol. 214, 21-44 (2005)

45. Teitler, Y. et al. Ubiquitous occurrence of basaltic-derived paleosols in the Late Archean Fortescue Group, Western Australia. Precambrian Res. 267, 1-27 (2015).

46. Marmo, J. S. The Lower Proterozoic Hokkalampi Paleosol In North Karelia, Eastern Finland. p. 41-66 (Springer, 1992).

47. Fedo, C. M., Wayne Nesbitt, H. \& Young, G. M. Unraveling the effects of potassium metasomatism in sedimentary rocks and paleosols, with implications for paleoweathering conditions and provenance. Geology 23, 921-924 (1995).

48. Hao, W., Flynn, S. L., Alessi, D. S. \& Konhauser, K. O. Change of the point of zero net proton charge $\left(\mathrm{pH}_{\mathrm{PZNPC}}\right)$ of clay minerals with ionic strength. Chem. Geol. 493, 458-467 (2018).

49. Hao, W. et al. The impact of ionic strength on the proton reactivity of clay minerals. Chem. Geol. 529, 119294 (2019).

50. Teitler, Y. et al. Petrology and geochemistry of scandium in New Caledonian Ni-Co laterites. J. Geochem. Explor. 196, 131-155 (2019).

51. Flombaum, P. et al. Present and future global distributions of the marine Cyanobacteria Prochlorococcus and Synechococcus. Proc. Natl Acad. Sci. USA 110, 9824-9829 (2013).

52. Sundby, B., Gobeil, C., Silverberg, N. \& Mucci, A. The phosphorus cycle in coastal marine sediments. Hydrobiologia 37, 1129-1145 (1993).

53. Konhauser, K. O. et al. Phytoplankton contributions to the trace-element composition of Precambrian banded iron formations. Geol. Soc. Am. Bull. 130, 941-951 (2018).

54. Albani, A. et al. Large colonial organisms with coordinated growth in oxygenated environments $2.1 \mathrm{Gyr}$ ago. Nature 466, 100-104 (2010).

55. Gauthier-Lafaye, F. \& Weber, F. Natural nuclear fission reactors: time constraints for occurrence, and their relation to uranium and manganese deposits and to the evolution of the atmosphere. Precambrian Res. 120, 81-100 (2003).

56. Mayika, K. B. et al. The Paleoproterozoic Francevillian succession of Gabon and the Lomagundi-Jatuli event. Geology 48, 1099-1104 (2020).
57. McInerney, F. A. \& Wing, S. L. The Paleocene-Eocene Thermal Maximum: a perturbation of carbon cycle, climate, and biosphere with implications for the future. Annu. Rev. Earth Planet. Sci. 39, 489-516 (2011).

58. Dypvik, H. et al. The Paleocene-Eocene thermal maximum (PETM) in Svalbard - clay mineral and geochemical signals. Palaeogeogr. Palaeoclimatol. Palaeoecol. 302, 156-169 (2011).

59. Pujalte, V., Baceta, J. \& Schmitz, B. A massive input of coarse-grained siliciclastics in the Pyrenean Basin during the PETM: the missing ingredient in a coeval abrupt change in hydrological regime. Clim. Past 11, 1653-1672 (2015).

60. Ossa, F. O. et al. Two-step deoxygenation at the end of the Paleoproterozoic Lomagundi Event. Earth Planet. Sci. Lett. 486, 70-83 (2018).

61. Melezhik, V. A., Fallick, A. E., Brasier, A. T. \& Lepland, A. Carbonate deposition in the Palaeoproterozoic Onega basin from Fennoscandia: a spotlight on the transition from the Lomagundi-Jatuli to Shunga events. Earth Sci. Rev. 147, 65-98 (2015).

62. Blättler, C. et al. Two-billion-year-old evaporites capture Earth's great oxidation. Science 360, 320-323 (2018).

63. Kreitsmann, T. et al. Hydrothermal dedolomitisation of carbonate rocks of the Paleoproterozoic Zaonega Formation, NW Russia-Implications for the preservation of primary C isotope signals. Chem. Geol. 512, 43-57 (2019).

64. Hao, W. et al. Clay minerals as a source of cadmium to estuaries. Sci. Rep. 10, 10417 (2020).

\section{Acknowledgements}

K.M. was supported by the Ministry of Education and Research of Estonia (Kristjan Jaak Scholarship program). K.M. and K.K. received further support from the Estonian Research Council grant PRG447 and P.S. from PUT1511. N.J.P acknowledges support from NASA Astrobiology Institute under Cooperative Agreement No. NNA15BB03A issued through the Science Mission Directorate. This work was supported by National Science and Engineering Research Council of Canada (NSERC) Discovery Grants to K.O.K. (RGPIN-165831) and D.S.A. (RGPIN-04134).

\section{Author contributions}

K.O.K. and W.H. conceived the study; W.H. performed all the P equilibrium adsorption experiments, $\mathrm{pH}$ edges, and dynamic adsorption experiments; W.H. and D.S.A. performed the surface complexation modeling of the adsorption data. W.H. compiled the database for P distribution in suspended sediments of modern river; K.M., P.S., M.M., A E.R., A.L., and K.K. provided information for the Francevillian Group and the Zaonega Formation, and the database for paleosol. Y.L. conducted the bacteria growth curve experiments. W.H., K.M. K.O.K., and N.J.P. wrote the manuscript with input from all coauthors.

\section{Competing interests}

The authors declare no competing interests.

\section{Additional information}

Supplementary information The online version contains supplementary material available at https://doi.org/10.1038/s41467-021-23304-8.

Correspondence and requests for materials should be addressed to W.H.

Peer review information Nature Communications thanks Frantz Ossa Ossa and Yoram Teitler for their contribution to the peer review of this work.

Reprints and permission information is available at http://www.nature.com/reprints

Publisher's note Springer Nature remains neutral with regard to jurisdictional claims in published maps and institutional affiliations.

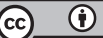

Open Access This article is licensed under a Creative Commons Attribution 4.0 International License, which permits use, sharing adaptation, distribution and reproduction in any medium or format, as long as you give appropriate credit to the original author(s) and the source, provide a link to the Creative Commons license, and indicate if changes were made. The images or other third party material in this article are included in the article's Creative Commons license, unless indicated otherwise in a credit line to the material. If material is not included in the article's Creative Commons license and your intended use is not permitted by statutory regulation or exceeds the permitted use, you will need to obtain permission directly from the copyright holder. To view a copy of this license, visit http://creativecommons.org/ licenses/by/4.0/.

(c) The Author(s) 2021 